\title{
Bridging the rural efficiency gap: expanding access to energy efficiency upgrades in remote and high energy cost communities
}

\author{
Suzanne MacDonald • Brooks Winner • Lisa Smith • \\ Juliette Juillerat • Sam Belknap
}

Received: 20 December 2018 / Accepted: 18 April 2019/Published online: 14 June 2019

(C) The Author(s) 2019

\begin{abstract}
Islands and remote rural communities throughout the USA pay some of the highest costs for electricity and heating fuel in the nation. For areas with such high energy costs, the benefits of energy efficiency can be significant but rural residents face several geographic, financial, and awareness barriers that make it difficult to invest in home energy upgrades. These barriers combine to create a market failure that we call the "rural energy efficiency gap." The existence of the rural efficiency gap is supported by data collected from Alaska, Maine, New Hampshire, and Vermont which indicate that the "energy burden," or percentage of household income spent on energy bills, is 33\% higher in rural areas and that participation in residential energy efficiency financing and rebate
\end{abstract}

Suzanne MacDonald and Brooks Winner contributed equally to this work.

S. MacDonald $\cdot$ S. Belknap $(\square)$

Island Institute, 386 Main Street, Rockland, ME 04841, USA

e-mail: sbelknap@islandinstitute.org

B. Winner

Metropolitan Area Planning Council, 60 Temple Pl, Boston, MA 02111, USA

\section{Smith}

Maine Governor's Energy Office, 62 State House Station,

Augusta, ME 04333, USA

J. Juillerat

Vermont Energy Investment Corporation, 128 Lakeside Avenue, Suite 401, Burlington, VT 05401, USA programs can be significantly lower. The combination of higher energy burdens and greater barriers to participation can lead to inequitable distribution of available resources for energy efficiency, meaning that those who could benefit most from efficiency upgrades are often least able to access them. This work is designed to be a resource for energy efficiency program administrators but may also be of interest to energy efficiency program implementers, policymakers, and regulators. It provides data about the rural energy efficiency gap and identifies barriers to energy efficiency in rural communities. It also highlights strategies that are helping to bridge the gap by making it easier for residents in cold climate, petroleum-dependent states-those with high thermal energy burdens - to increase comfort and safety in their homes while also reducing energy bills. The barriers to rural energy efficiency identified in this paper have been grouped into three categories: geographic barriers, financial barriers, and awareness and access barriers. There are many differences between rural areas across the country, e.g., demographics, utility model and rate structures, energy sources, and consumption patterns. This paper is not intended to suggest that the strategies documented here will necessarily be applicable to all rural areas in the USA

Keywords Energy efficiency · Rural efficiency gap · Energy burden · Program design - Weatherization - Rural communities 


\section{Introduction}

The Bridging the Rural Efficiency Gap Project was a two-year project initiated by the Maine Governor's Energy Office ${ }^{1}$ in which our sub-awarded team researched the barriers to residential energy efficiency in four participating rural states - Alaska, Maine, New Hampshire, and Vermont - and identified approaches to increase participation in energy efficiency programs that we refer to as "bridging strategies." Even though Maine's energy burden (the percentage of annual household income that goes toward energy bills) is one of the highest in the country, we observed a host of factors that were limiting investment in efficiency upgrades in rural areas of the state. These included limited access to energy efficiency contractors, a general lack of awareness of available resources, and the increased cost of transporting goods and services. Our goals for the project were to further analyze these issues in Maine, to share elements of program design and implementation that we had seen as successful in our state, and to identify additional strategies and resources that could be applied to overcome barriers to energy efficiency program participation in Maine and in other heating-dominated regions of the USA. Some of these strategies may also be applicable to cooling-dominated regions as well.

This paper was designed to be a resource for those best positioned to increase access to energy efficiency in rural areas, stakeholders we refer to as "program administrators" and "program implementers." Program administrators respond to policy mandates (most commonly from the state level) with the design and coordination of energy efficiency programs and are most often housed within a state agency, utility, or statewide efficiency trust. For simplicity, we will refer to these as "administrators" in this paper. Program implementers operate at the intersection between program administrators and residential customers and can include contractors, municipalities, and nonprofit organizations. For simplicity, we will refer to these as "implementers" in this paper.

This paper was created to enhance the regional and national understanding of the factors at play in rural energy efficiency projects through data analysis and

\footnotetext{
${ }^{1}$ The Maine Governor's Energy Office is the designated State Energy Office (SEO), is responsible for planning and coordinating state energy policy, and serves as the primary energy policy advisor to the Governor in Maine.
}

case studies offered from the perspectives of both administrators and implementers. For those interested in further exploring this issue and the tools that are helping to close the gap, we compiled a host of supporting materials, including an extended version of this paper. ${ }^{2}$

\section{Defining the rural energy efficiency gap}

The "energy efficiency gap," or "energy efficiency paradox," describes the slow rate of uptake of energy efficiency products and services even when they are economically beneficial (Jaffe and Stavins 1994). Researchers have debated the existence and size of the gap (Gerarden et al. 2015), whether addressing the gap represents a "win-win" for both energy efficiency and carbon reductions (Fowlie et al. 2018), and extensive research has been conducted to explain the reasons for the gap and solutions to bridge it (Gillingham and Palmer 2014). Energy efficiency financial assistance programs (including rebates, grants, or loans) offered by electric and natural gas utilities, statewide energy efficiency entities, and state and federal agencies are designed to close this gap by providing incentives for adoption of energy efficiency measures and reducing the barriers that impede deployment of these measures.

However, to date, little research has been done on whether and how this proposed gap manifests itself in rural and remote communities in the USA.

Rural residents face a distinct set of energy efficiency adoption barriers that create a market failure we call the "rural efficiency gap." This term describes the seemingly slower uptake of energy efficiency upgrades in small, isolated communities even when higher energy costs and energy burdens (defined as the percentage of annual household income spent on heat and electricity) often make these home improvements even more costeffective than in areas with lower energy prices. The rural efficiency gap exists in many rural places, because the barriers to accessing energy efficiency, including access to experienced contractors, geographic isolation, appropriate financing mechanisms, and general awareness of energy efficiency programs, often vary from those experienced in more populated areas.

The theory that this gap exists was initially based on observations by members of our research team who

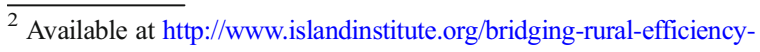
gap 
observed the Island Institute ${ }^{3}$ and their work implementing energy efficiency programs with Maine island residents. Maine island households pay as much as a dollar more per gallon for fuel oil than their neighbors on the mainland. Yet, prior to the first local weatherization initiative organized by the Island Institute and its community partners in July 2012, only 13 island homes (less than $1 \%$ of the homes in Maine's 15 yearround island communities) had participated in Efficiency Maine's rebate program for residential thermal efficiency upgrades. Since 2012, the Island Institute has supported more than 400 island homes (approximately $20 \%$ ) in accessing Efficiency Maine's programs and complete weatherization and heating system upgrades.

Through this work, and the reactions it received from stakeholders in Maine, the Institute identified several geographic, financial, and awareness barriers facing rural households. In an effort to better understand strategies for dealing with these barriers, we sought to investigate if comparable challenges were present in other similarly situated, rural, heating-dominated areas of the country. We expected that the existence of this gap would be particularly relevant to states similar to Maine with cold climates, high dependence on heating oil, and at least one-third of residents living in rural areas like Alaska, New Hampshire, and Vermont. We partnered with energy efficiency administrators and implementers from those states to determine whether the gap existed in those places as well.

\section{Why rural matters}

One in every five Americans lives in a rural area (Census Bureau 2016). Rural communities have historically fed and powered our nation. They make important contributions to our economy, our culture, and our history. While rural areas produce much of the energy consumed in the USA (e.g., oil, gas, wood, wind, etc.), they often pay higher energy prices than more populated areas (ACEEE 2018) and the median energy burden is $33 \%$ higher for rural households than the national median (Ross et al. 2018). Compounded by challenges such as declining population growth, decreasing

\footnotetext{
3 The Island Institute is a nonprofit community development organization that works to sustain Maine's island and coastal communities, and shares ideas and experiences that further the sustainability of communities in Maine and elsewhere. www.islandinstitute.or
}

educational attainment, and unemployment, this disproportionately high energy burden underscores how rural places are often being left behind in the U.S. economy.

While this paper has a clear focus on rural communities, we acknowledge that the terms "rural" and "remote" have different meanings in different regions (Yuan 2015). In small states such as Vermont and New Hampshire, services are, at worst, a few hours away by road. Maine has 15 year-round, unbridged island communities accessible only by boat or plane. Many rural villages in Alaska are entirely off the road system, so all vendors and supplies must be brought in by plane or boat at great expense. Unless otherwise noted, we use the Census Bureau's definition of rural as any place outside of an "urbanized area" (population of 50,000 or more) or an "urbanized cluster" (population of at least 2500 and less than 50,000). When referring to "remote" communities, we mean those that are either only accessible by plane or boat at least some of the year or those that are otherwise geographically isolated from population centers (e.g., communities in northern New Hampshire separated from the rest of the state by the White Mountains).

Despite these differing definitions of rural and remote, we found that Alaska, Maine, New Hampshire, and Vermont share similar barriers to participation in energy efficiency and there is much that each state can learn from the others. Some of these similarities, including the high percentage of rural population, high dependence on petroleum fuels for heating, and high per capita energy expenditures, are highlighted in Table 1. Notably, these four states are all in the top 15 for rural population, top six for percent of homes heated with fuel oil, and top 25 for energy expenditures per capita.

Rural households face unique challenges when it comes to making investments in energy efficiency. The median household income for rural households is about $4 \%$ lower than the median for urban households (Census Bureau 2016), but rural residents pay more for electricity and heating oil than their urban counterparts (BLS 2013). This means that rural residents often have higher energy burdens than non-rural households (e.g., Sears 2018), spending a higher percentage of their income on energy than their urban counterparts. The median energy burden among rural households in the USA is $4.4 \%$, compared with the national median burden of $3.3 \%$ (Ross et al. 2018). In many rural households, the energy burden exceeds $6 \%$, the threshold considered unaffordable by some researchers (Fisher et al. 2017). Low- 
Table 1 Summary of key demographic indicators

\begin{tabular}{lllll}
\hline & Alaska & Maine & New Hampshire & Vermont \\
\hline Percent population in rural areas (rank) $^{\mathrm{A}}$ & $33.9 \%(14 \mathrm{th})$ & $61.3 \%(1 \mathrm{st})$ & $39.7 \%(11 \mathrm{th})$ & $61.1 \%(2 \mathrm{nd})$ \\
Percent of homes heated with fuel oil (rank) $^{\mathrm{B}}$ & $29.8 \%(6 \mathrm{th})$ & $61.3 \%(1 \mathrm{st})$ & $43.1 \%(2 \mathrm{nd})$ & $41.8 \%(3 \mathrm{rd})$ \\
Percent of homes built before $1940\left(\right.$ rank) $^{\mathrm{C}}$ & $1 \%(51 \mathrm{st})$ & $23 \%(8 \mathrm{th})$ & $21 \%(12 \mathrm{th})$ & $24 \%(7 \mathrm{th})$ \\
Energy expenditures per capita (rank) $^{\mathrm{D}}$ & $\$ 6241(2 \mathrm{nd})$ & $\$ 3968(9 \mathrm{th})$ & $\$ 3515(21 \mathrm{st})$ & $\$ 3830(13 \mathrm{th})$ \\
Average energy burden $^{\mathrm{E}}$ & $5 \%$ & $6 \%$ & $5 \%$ & $5 \%$ \\
\hline
\end{tabular}

${ }^{\mathrm{A}}$ Census Bureau: https://www.census.gov/geo/reference/ua/urban-rural-2010.html

${ }^{B}$ U.S. Energy Information Agency: https://www.eia.gov/state/compare/

${ }^{\mathrm{C}}$ Census Bureau: https://factfinder.census.gov/faces/tableservices/jsf/pages/productview.xhtml?pid=ACS_16_1YR_B25034\&prodType= table (2016 data)

${ }^{D}$ EIA: https://www.eia.gov/state/seds/data.php?incfile=/state/seds/sep_sum/html/rank_pr.html\&sid=US. Personal transportation fuel use is included in these figures

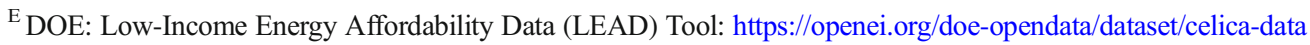

income households in rural areas are disproportionately impacted by high energy expenditures (Gilleo 2018). Figure 1 shows that energy burdens are often much higher in rural areas isolated from population centers.

One reason for the higher energy burden is that many rural communities are more dependent on petroleum fuels for heating (heating oil, liquefied petroleum gas, kerosene, and diesel) due to the limited reach of natural gas infrastructure. For example, Maine leads the nation in dependency on home heating oil with more than $60 \%$ of households using petroleum fuels for space heating; nearly half of all homes in New Hampshire do the same (EIA 2016). A large portion of those households heating with petroleum are located in rural areas where natural gas service is not and likely will never be economically viable, and other alternatives such as bulk delivery of wood pellets may not be available. Petroleum fuel prices are more volatile and are often purchased with a large upfront payment upon delivery rather than with costs spread out more evenly over the heating season as with natural gas or electricity. This can make heating with petroleum fuel costly and challenging, particularly for low-income residents. In many remote Alaska villages, for example, fuel oil is the only option for space heating and can be as much as $\$ 10$ per gallon due to the added cost of transporting petroleum fuels and the absence of a competitive marketplace (i.e., many rural communities have only one fuel distributor) (Mooney 2015).

The absence of a centralized heating fuel utility can also limit funding for thermal energy efficiency programs as many states fund them with surcharges collected from electricity and natural gas utilities. The lack of a centralized heating utility also means that alternative financing options such as on-bill financing are limited in many rural places. Figure 2 shows that Alaska, Maine, New Hampshire, and Vermont are some of the only states in the nation where petroleum fuels remain a major source for space heating.

The age and condition of the housing stock can also be a cause of high energy burden in rural areas. Maine, New Hampshire, and Vermont have some of the oldest housing stock in the nation (see Table 1), with rural areas of those states tending to have older housing stock and a percentage of mobile homes that increases as the percentage of rural population increases (Island Institute 2018). Older homes and mobile homes are often less energy efficient than newer homes. For example, in Maine, older homes have been found to be less efficient than newer homes (NMR Group, Inc. 2015) and across the USA, residents of mobile homes spend $70 \%$ more per square foot on energy than those living in sitebuilt homes (Ross et al. 2018). These conditions can be exacerbated in homes owned or occupied by families with low incomes. In a 2018 study, the Maine Office of the Public Advocate found that more than $50 \%$ of low-income homes had insufficient wall insulation and only $9 \%$ of low-income homes had an attic insulation rate to the standards set by Efficiency Maine (R-49) (GDS Associates 2018). The existence of the rural efficiency gap is further supported by data collected from each state indicating that participation rates in energy efficiency financing and rebate programs can be lower. 


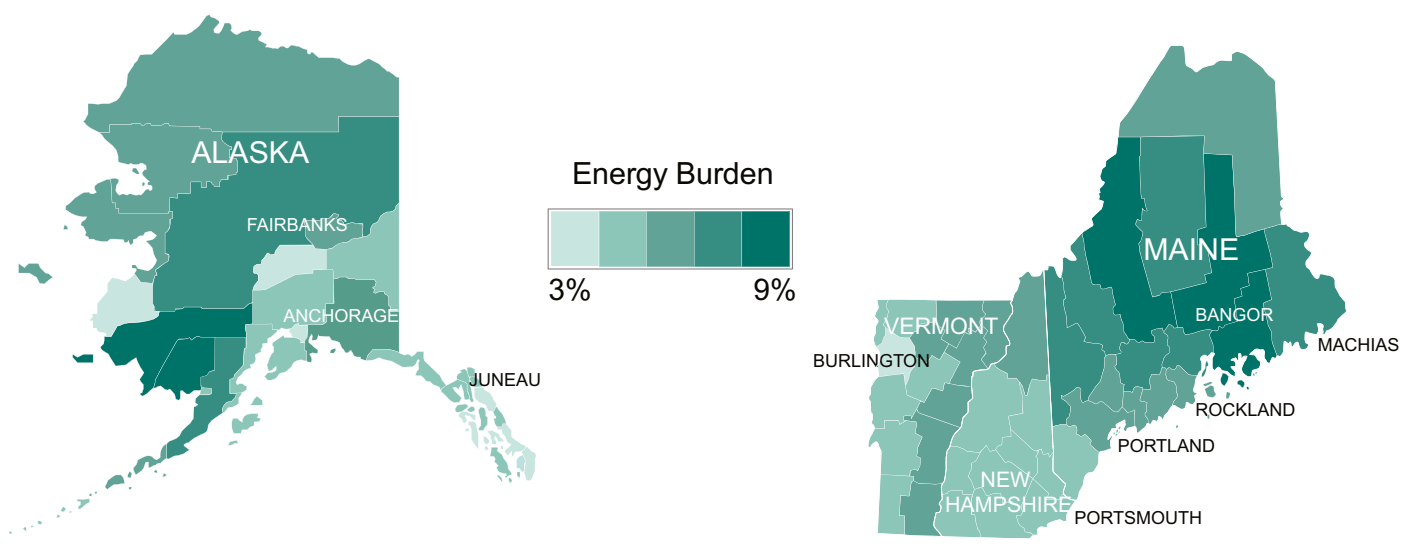

Fig. 1 Energy burden by county or borough in the four states. Source: DOE Low-Income Energy Affordability Data (LEAD) Tool (2015)

\section{Methodology}

Our research focused primarily on programs supporting residential weatherization measures, such as air sealing and insulation in single-family homes and one-to-fourunit buildings in heating-dominated regions. We began our inquiry by reviewing the financial assistance programs offered in each state for residential energy efficiency. We then conducted interviews with more than 50 energy efficiency administrators and implementers of local energy efficiency initiatives in Alaska, Maine, New Hampshire, and Vermont.

After our interviews, we analyzed program data provided to us by administrators to determine where rural and remote residents might have lower participation rates in energy efficiency programs. To provide additional context on the rural efficiency gap and to supplement existing literature on rural energy issues, we compiled case studies to highlight how bridging models are being used in each state to address the barriers to rural energy efficiency. The case studies were developed using data and materials collected from the implementers and administrators we interviewed.

Our work was guided by an advisory group of experts from the four participating states that met four times during the project and represented the following organizations: Alaska Energy Authority, Efficiency Maine, Efficiency Vermont, the Maine Office of the Public Advocate, Mitsubishi Electric, the New Hampshire Office of Strategic Initiatives, Renewable Energy Alaska Project, and Vital Communities.

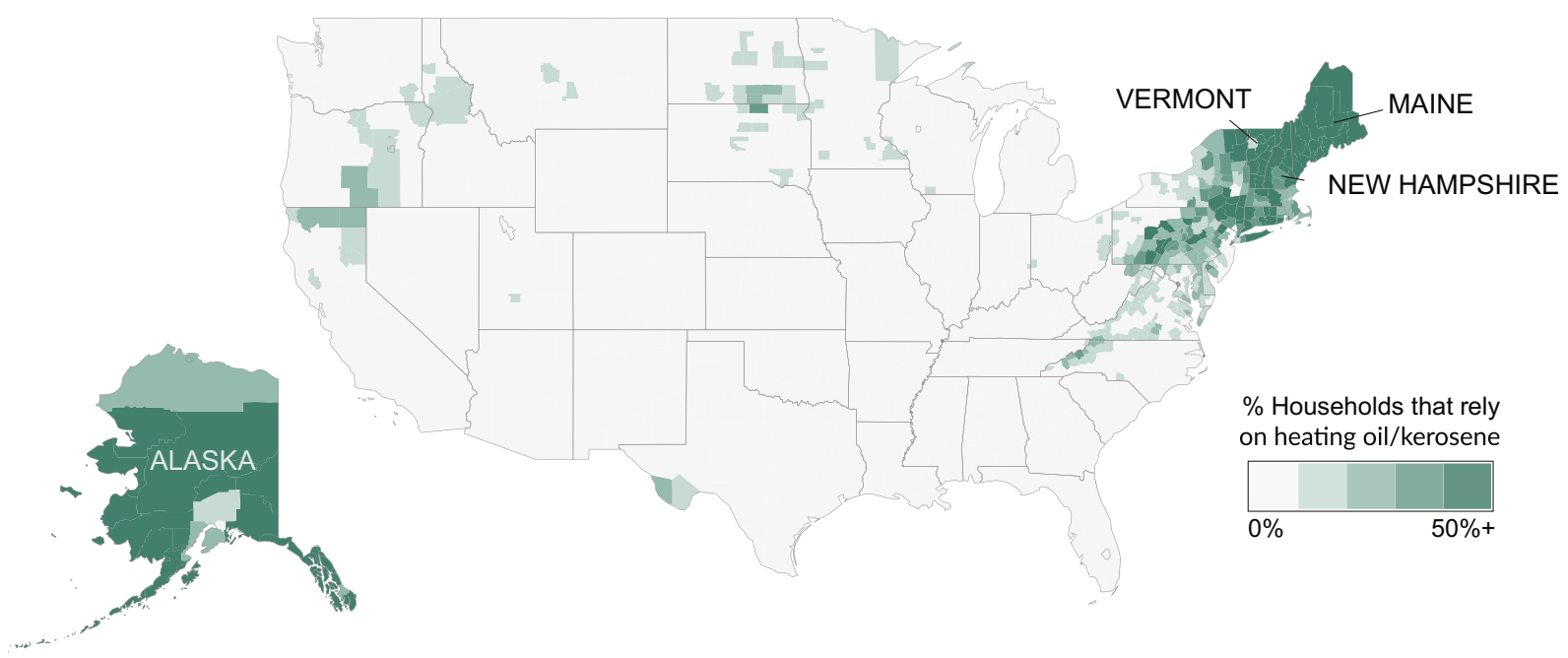

Fig. 2 Percent of households (by county) heating with oil and kerosene in the USA. Source: Census Bureau, American Community Survey (2016) 
Some important parts of the energy efficiency landscape in rural communities could not be included in our research. Our research focused primarily on programs supporting home weatherization measures, such as air sealing and insulation, although some states like Maine and Vermont also offer incentives for other thermal efficiency measures, including heating systems and domestic hot water heaters. While there are many other effective approaches in increasing the adoption of energy efficiency measures and products (e.g., lighting) in rural homes, this paper is focused solely on weatherization measures. Due to our focus on single-family homes, we acknowledge that our findings may have limited applicability to multifamily housing in rural areas. We also acknowledge that our work has a strong focus on the role of mission-driven nonprofit organizations as implementers, as opposed to contractors and municipalities.

There are many differences between rural areas across the country, e.g., demographics, utility model and rate structures, energy sources, and consumption patterns. This paper is not intended to suggest that the strategies documented here will necessarily be applicable to all rural areas in the USA.

Further research is needed to develop a more complete picture of the rural efficiency gap and solutions to bridge the gap in these four states and in other parts of the country.

\section{Summary of residential weatherization programs offered in Maine, New Hampshire, Vermont, and Alaska}

Many state and federal agencies offer financial assistance programs (i.e., rebates, grants, and loans) to encourage investments in residential energy efficiency upgrades. At the federal level, the U.S. Department of Energy's Weatherization Assistance Program (WAP) and the U.S. Department of Agriculture's SingleFamily Housing Repair Loan and Grant Program have been established to assist underserved populations, including low-income and elderly residents, in making home energy efficiency upgrades. Funding for these programs often falls short of the demand, and anecdotally, waiting periods for WAP can be as long as 1015 years.

At the state level, financial assistance programs are often driven by statewide goals or legislative mandates to increase energy efficiency. For example, Maine has a statutory goal of weatherizing $100 \%$ of homes (whose owners are willing to participate) by 2030, and Alaska has a statewide goal of improving energy efficiency 15\% between 2010 and 2020 (AEA 2017). To reach these goals, states will need to address the rural efficiency gap in order to deploy energy efficiency at scale.

Each of the four states has considered weatherization programs aimed at helping residents seal and insulate their homes. These federal programs are complemented in some states by incentive programs with no income requirements administered by utilities or third-party administrators. Maine, New Hampshire, and Vermont currently also offer a weatherization incentive program without income eligibility requirements. Alaska offered a rebate program without income requirements which was suspended in 2016 due to budget shortfalls. That program is included for comparison purposes.

Table 2 summarizes the incentive programs offered in each state in addition to WAP. The weatherization incentive programs summarized are available to single-family residences and rentals of one to four units. In Alaska and Maine, the programs are available only to primary residences of yearround residents. In New Hampshire, the program is targeted at homes with high energy usage, as assessed through a Home Heating Index. The incentive structure and contractor eligibility requirements vary by state.

In all four states, the programs are fuel neutral, ${ }^{4}$ but in Maine and Vermont, additional incentives are available for natural gas customers through their utility for heating system upgrades or for insulation. However, rural residents do not typically have access to natural gas, and therefore to these additional incentives. In addition to an incentive program, the four states offer financing programs that are open to all program participants. Vermont's Heat Saver Loan offers a lower interest rate for lower-income applicants, but loan programs targeted specifically at lower-income residents are not common in the states considered.

\footnotetext{
${ }^{4}$ Fuel-neutral programs are open to any household regardless of whether they heat with natural gas, heating oil, propane, electricity, or another fuel type.
} 


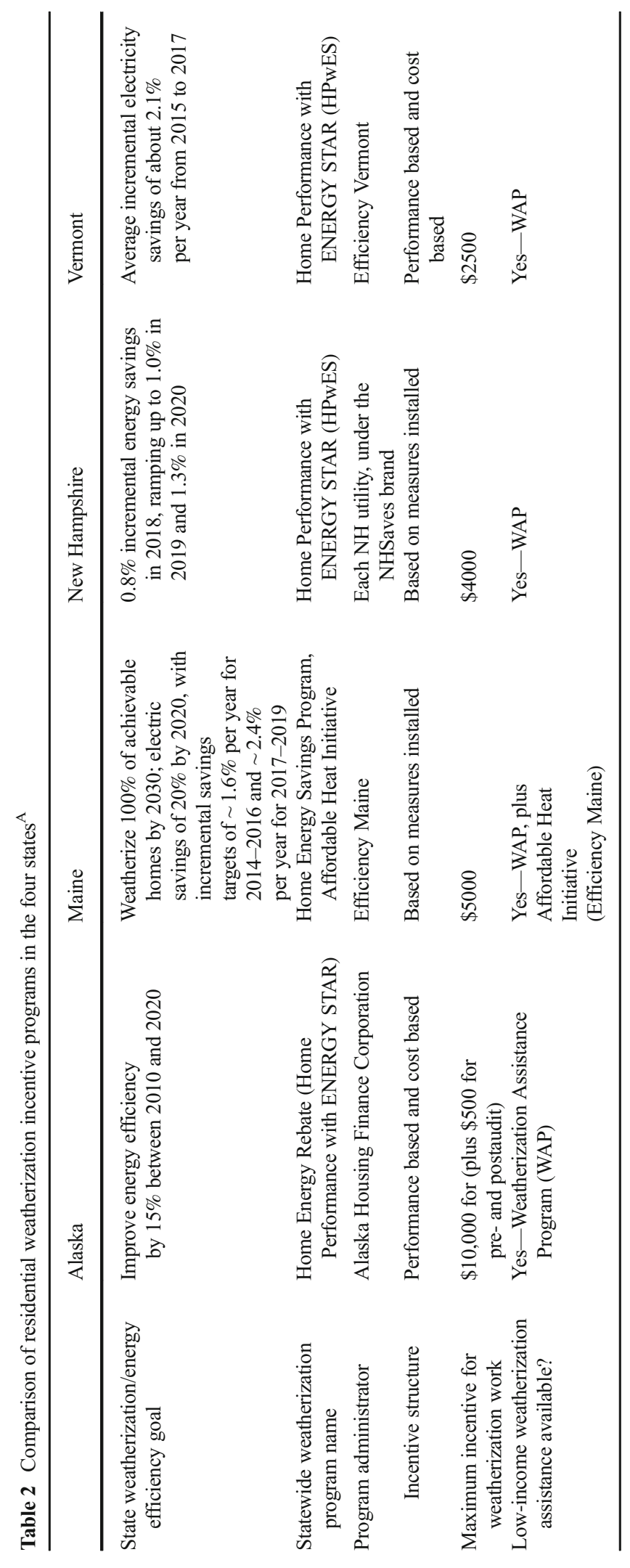




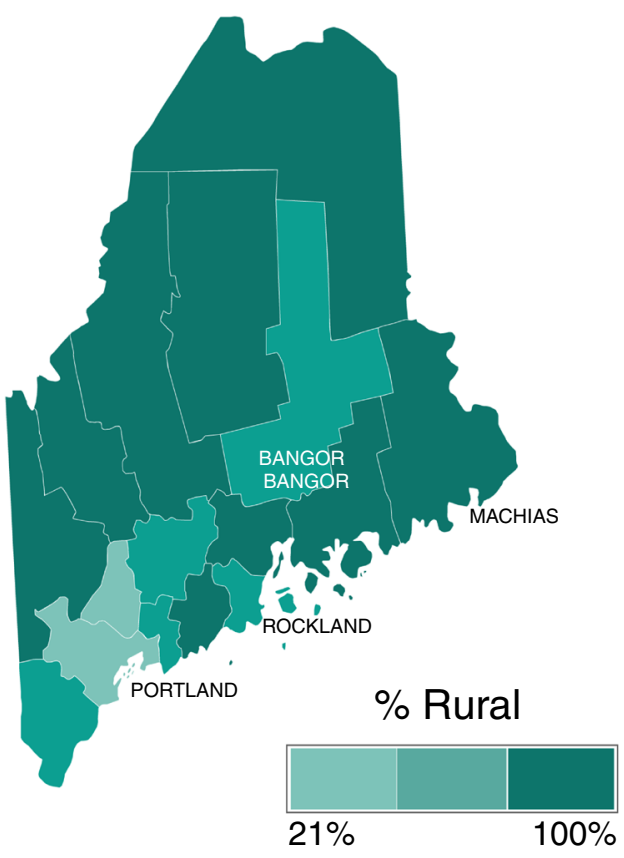

Source: US Census

Fig. 3 Percent rural population (left) vs. Efficiency Maine participating households per housing unit by county (right). Sources: Efficiency Maine Home Energy Savings Program and Affordable

\section{Program participation in rural states}

To determine whether there were differences in participation between rural and non-rural areas, we analyzed data about program participation provided by administrators from Alaska, Maine, New Hampshire, and Vermont. Figure 3 shows that participation in Efficiency Maine's Home Energy Savings Program (EMHESP) has been concentrated in counties with major population centers. Rural counties in the remote eastern and western parts of the state have seen the lowest participation rates. These low rates of participation, however, are not consistent across all rural areas, which may suggest that the rural efficiency gap can be bridged. Efficiency Maine has made efforts to build a statewide network of contractors serving rural and urban communities alike and has designed its rebate and loan programs to be accessible to residents across a wide range of incomes.

A similar analysis for New Hampshire did not reveal a significant difference in participation in rural areas, yet challenges of a different sort were identified. While Fig. 4 does not indicate any clear pattern of participation in the low-income program or the Home Performance with ENERGY STAR (HPES) in rural areas of the state,

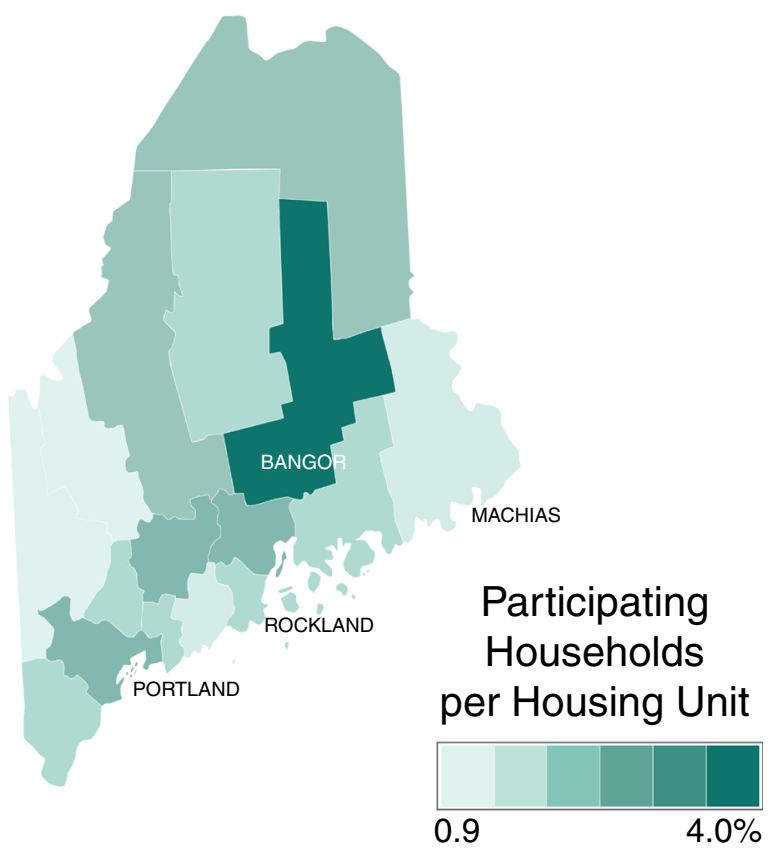

Source: Efficiency Maine

Heat Initiative Participating Households for Fiscal Years 2016 and 2017; Census Bureau (2010).

stakeholders from New Hampshire shared that thermal efficiency programs have traditionally been funded at levels well below the existing demand, meaning that weatherization programs are consistently over-subscribed. This may be because the HPES program is funded exclusively with electric ratepayer funds and that the cost-effectiveness of the program is measured through electricity and natural gas savings. Unlike its neighbors Maine and Vermont, New Hampshire does not use revenues from the Regional Greenhouse Gas Initiative (RGGI) to fund its energy efficiency programs (RGGI 2019). RGGI funds have been a crucial source of stable funding for the weatherization incentive programs administered by Efficiency Maine and Efficiency Vermont. New Hampshire stakeholders also noted that existing programs may not be serving the moderateincome customer segment whose incomes are too high to qualify for income-eligible programs and for whom the cost of a HPES project (average cost of \$6000) may be unaffordable.

In Vermont, program participation data did not show a strong correlation between the percentage of rural population and participation in Efficiency Vermont's HPES program but there does appear to be a slight 
Participation in Low-Income
Program Per Housing Unit
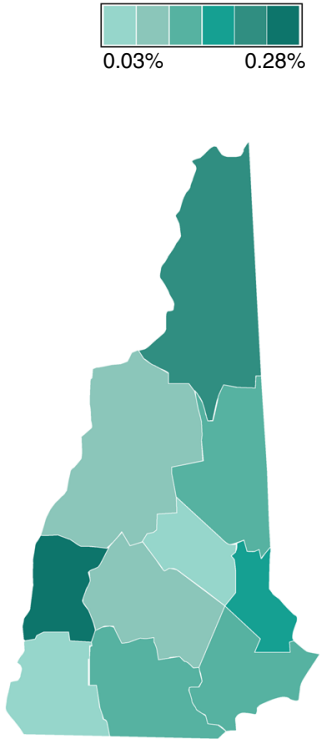

Home Performance with ENERGY STAR Program Participation Per Housing Unit
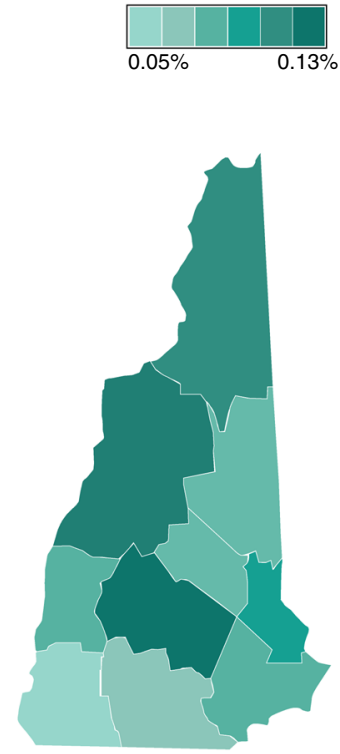

$\%$ Rural
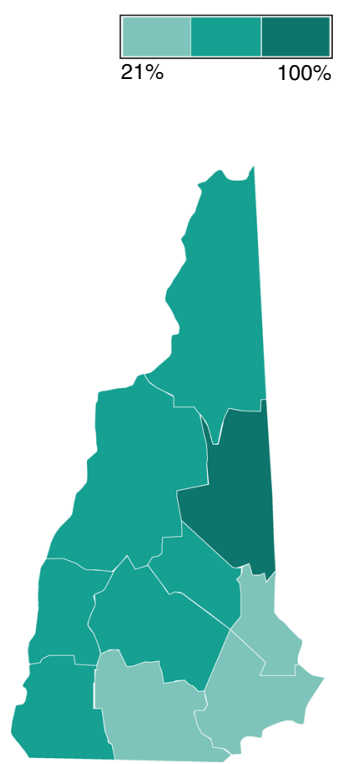

Source: NHSaves (2018) and Census Bureau (2010)

Fig. 4 New Hampshire's participation in Low-Income Program per housing unit, Home Performance with ENERGY STAR program participation per housing unit, and percent rural population. Sources: NHSaves (2018); Census Bureau (2010).

decrease in program participation as the percentage of rural population increases (Efficiency Vermont 2017). Like New Hampshire, the average cost of a HPES project (\$7800) may be unaffordable for many moderate-income residents who do not qualify for income-eligible programs. However, through a performance measure that is used to evaluate program efficacy, Efficiency Vermont is seeking to ensure that efficiency funds are equitably distributed by county. Efficiency Vermont is also designing programs that may be more effective in rural places such as its Do-It-Yourself rebate program.

In Alaska, program participation data show that the state's approach to designing programs with rural communities in mind can make a difference. Alaska's Weatherization Program was designed to be accessible to income-eligible households in both urban and rural areas, offering up to $\$ 30,000$ per home for weatherization upgrades. This level of funding was key to addressing the high upfront cost of this work, particularly for transportation costs related to serving the state's most remote, difficult-to-reach communities located off the road system. This program is supported by community- based organizations and initiatives such as the RurAL CAP Energy Wise program highlighted in the case study below. As a result, residents throughout the state have been able to use the program. In contrast, the Alaska Housing Finance Corporation's Home Energy Rebate program was, by design, not targeted specifically at rural communities and therefore, participation was limited primarily to the "Railbelt," the region defined by the electric grid serving the more populated AnchorageFairbanks areas. The maps in Fig. 5 show the different spatial reach of the two programs. The difference in the physical locations of participation between these two programs demonstrates that energy efficiency projects are possible in all parts of the state if they are designed to address the barriers to serving rural communities.

\section{Barriers to rural energy efficiency}

Through interviews conducted with administrators and implementers from the four participating states, and analysis of available program participation data, we identified the barriers listed below. While some of these 
Program participation in the Home Energy Rebate Program

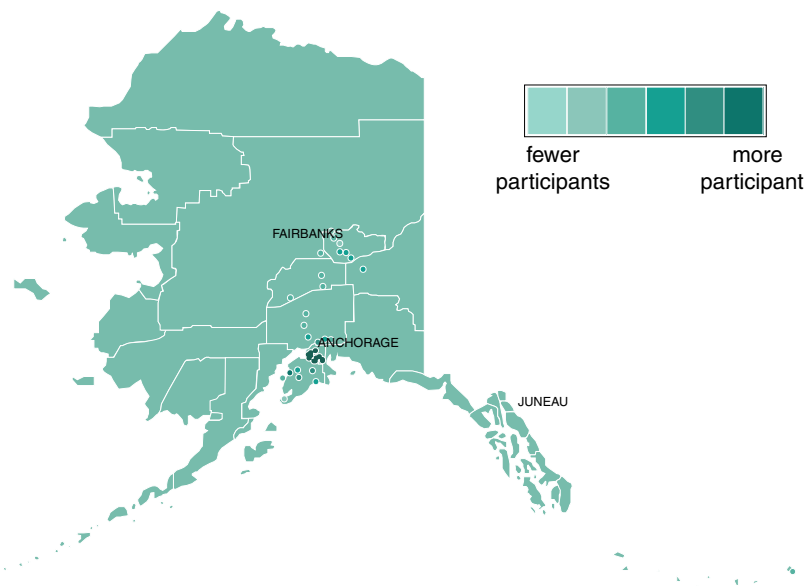

Program participation in the Weatherization Program

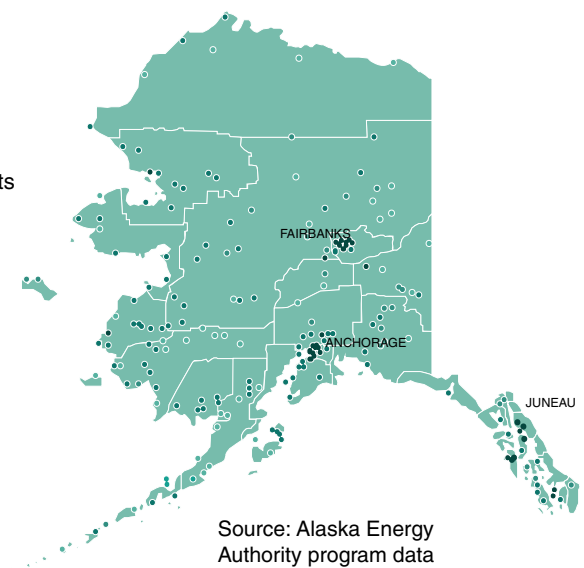

Fig. 5 Program participation in the Home Energy Rebate Program and the Weatherization Program. Source: Alaska Energy Authority Program Data (2008-2015)

barriers may not be unique, we found that they are often exacerbated in rural communities. These barriers fall into three categories: geographic barriers, awareness and access barriers, and financial barriers.

\section{Geographic barriers}

\section{Geographic isolation}

Rural communities can be challenging places to live. Physical distance from resources (e.g., human, financial) is often further exacerbated by lack of economies of scale in small communities, making it harder for rural residents to access financing, incentives, and professional services to implement energy efficiency projects. For example, Maine island residents interested in signing up for federally funded weatherization assistance through the Community Action Program low-income program must qualify for the federal Low-Income Home Energy Assistance Program (LIHEAP) (MSHA 2019). To sign up for LIHEAP, they must travel by ferry to an office on the mainland, adding time and expense. As outlined below, the geographic challenges of small, sparsely populated towns can be a significant barrier to energy efficiency.

\section{Workforce availability}

In many instances, there is a lack of qualified contractors willing to serve rural areas and/or unavailability of a local, skilled workforce to complete energy efficiency upgrades. For example, in rural Northern Vermont, there are very few contractors participating in Efficiency Vermont's HPES program (Juillerat, VEIC, Personal Communication, September 2018). Similarly, as of October 2018, there are no energy auditors based on any of the Maine islands that are registered to work under EMHESP (Efficiency Maine 2018). Figure 6 shows the distribution of contractors participating in residential weatherization programs in Maine, New Hampshire, and Vermont. These maps illustrate how efficiency services are often more difficult to obtain in rural areas.

Financial barriers

\section{Upfront cost}

The high upfront cost of energy upgrades is a barrier to energy efficiency, particularly for low-income households (e.g., EDF 2018). This barrier can create an "energy efficiency gap" in which homeowners do not invest in efficiency upgrades even if they know that they will save money in the long run because the out-ofpocket cost is too high. In some cases, this gap can be exacerbated in rural areas due to additional costs associated with travel to remote areas. Anecdotally, these additional expenses can increase the overall cost of an energy upgrade by more than $50 \%$ in isolated communities (MacDonald, Island Institute, Personal Communication, August 2018). For example, the cost of barging 


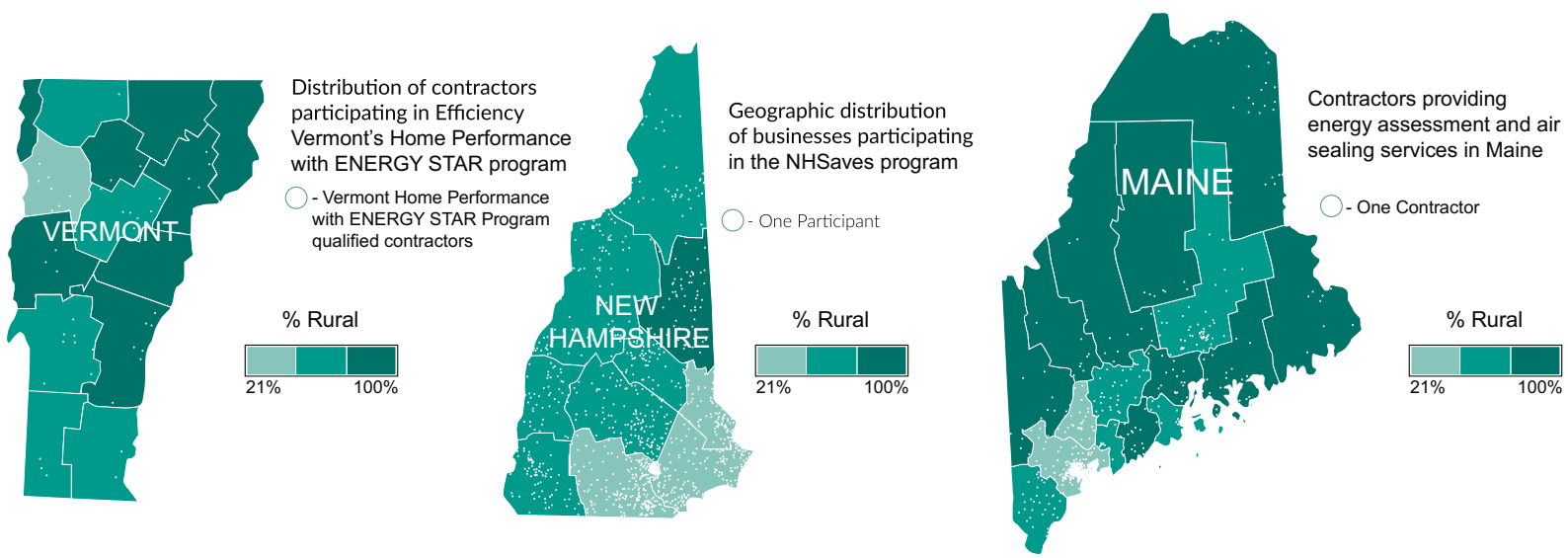

Fig. 6 Contractors and businesses participating in Weatherization Incentive Programs in Vermont, New Hampshire, and Maine. Sources: Efficiency Vermont website (April 2018); NHSaves (2018); and Efficiency Maine website (March 2018).

an insulation truck to Monhegan Island, Maine, can be around $\$ 2000$, a cost that is passed on entirely to one customer unless the work is arranged in a way that lines up multiple customers to share the cost (Ibid).

\section{Lower incomes and higher energy burden}

Median income is lower in rural parts of Alaska, Maine, New Hampshire, and Vermont (Census Bureau 2016), and energy burden increases along with the percentage of rural population in all four participating states (Juillerat VEIC, Personal Communication, September 2018), meaning that rural residents often pay a greater proportion of their incomes toward their utility bills (e.g., Sears 2018). Therefore, rural residents often cannot afford the necessary efficiency upgrades and are more susceptible to the "energy efficiency gap" than their more urban counterparts.

\section{Credit access and debt aversion}

While financing tools like loans and even on-bill financing with traditional credit requirements offer access to capital for home energy upgrades, these tools may not be accessible to rural communities. For example, Vermont's 2011 Comprehensive Energy Plan identified financing aversion as a key barrier to increased investment in energy efficiency (Vermont Department of Public Service 2011) and a 2015 survey of moderateincome Vermont residents found that more than threequarters of respondents were unwilling to take on debt to finance efficiency upgrades (EFG 2018). Similarly, analysis of a pilot program conducted in Maine to promote the use of air-source heat pumps showed that only $13 \%$ of program participants took advantage of onbill financing when it was offered (EMI Consulting 2014). Most rural customers in Alaska and Maine are not served by a heating fuel utility and therefore do not have access to on-bill financing for thermal efficiency measures.

Awareness and access barriers

\section{Lack of access to traditional marketing channels}

Success of traditional marketing strategies may be limited in rural areas. For example, programs that rely heavily on online marketing may not effectively reach rural communities where access to reliable broadband internet is often limited (NAS 2016). In states with older populations like Maine, New Hampshire, and Vermont, many residents may not have any access to internet whatsoever. Weatherization contractors tend to advertise in their own service territories, but for those remote communities not served by a local contractor (e.g., rural Alaska villages and Maine islands), there may be very low awareness of available programs.

\section{Lack of awareness or skepticism of existing resources}

Residents of small towns and rural communities often rely on word-of-mouth recommendations from neighbors and "trusted messengers" (third parties with no vested interest in selling products or services), when deciding to make home improvements. If no one in their community has weatherized their home, residents may 
not be aware of existing financial assistance programs. A cultural or financial preference to "do it themselves" and/or skepticism of assistance programs that require the use of contractors to complete the work may further limit participation in programs (MacDonald, Island Institute, Personal Communication, August 2018).

\section{Addressing the barriers}

To respond to these barriers, administrators and implementers in the four participating states have developed a number of "bridging models." These include new program designs and strategies that prioritize equitable access to financial assistance, innovative models that lower barriers to participation, and creative partnerships that increase the accessibility and effectiveness of efficiency programs. Many of these strategies align with the recommendations highlighted in ACEEE's report Reaching Rural Communities with Energy Efficiency Programs (Shoemaker et al. 2018).

The following case studies provide examples of bridging models in practice and demonstrate how they are connecting rural communities across Alaska, Maine, New Hampshire, and Vermont with financial assistance for energy efficiency, therefore removing the barriers facing rural communities. These models often combine multiple strategies to help bridge the "rural efficiency gap," and we believe they have relevance in other rural regions beyond the four participating states. These bridging models and case studies are also featured in the Bridging the Rural Efficiency Gap Toolkit, which includes templates and information for those interested in replicating the models featured on the websites of the Island Institute and the Governor's Energy Office (Island Institute 2018).

\section{Case studies}

To provide additional context on the rural efficiency gap and to supplement existing literature on rural energy issues, we compiled case studies to highlight how bridging models are being used in each state to address the barriers to rural energy efficiency. The case studies were developed using data and materials collected from the implementers and administrators we interviewed.
Addressing geographic barriers

\section{Geographically equitable program design}

Some states have designed policy and programs that result in an equitable implementation of efficiency programs for rural communities. For example, one of the criteria that the Vermont Public Utility Commission uses to evaluate Efficiency Vermont's energy efficiency programs is a "geographic equity indicator," which stipulates that funds should be distributed equitably across the state (Vermont Public Utility Commission 2017). In Alaska, low-income households in communities located off the road system (i.e., rural villages) qualify for enhanced financial assistance through the Weatherization Program that is designed to work in rural areas and that provides funds to cover the added cost to serve them (DOE 2016). As demonstrated in Fig. 5, this program has supported weatherization upgrades in homes in rural areas throughout the state.

\section{Aggregated demand and collective purchasing}

Aggregated demand is a programmatic approach that leverages the power of collective purchasing to increase consumer interest in energy efficiency and achieve economies of scale in small, rural communities. This reduces upfront costs, logistical barriers, and awareness barriers. In rural places where sufficient demand and economies of scale are lacking, aggregated demand and collective purchasing can provide an extra incentive for contractors to provide services in underserved markets. The Weatherization Weeks organized by the Island Institute and its community partners deploy aggregated demand and collective purchasing to bring weatherization services to remote island communities in Maine (see the Weatherization Week case study below).

\section{Community partnerships}

Creative partnerships between community organizations, energy efficiency contractors, and administrators like those seen in Vermont and New Hampshire through Vital Communities' Weatherize Upper Valley program can significantly increase participation in rural towns (see the Weatherize case study). 


\section{Hire and train local labor}

Hiring local residents to complete energy efficiency upgrades in their own communities can be an effective way to address workforce shortages and benefit local economies. For example, the Rural Alaska Community Action Program's Energy Wise program hires local residents to conduct energy assessments and install energy efficiency measures, using a neighbor-to-neighbor approach and creating local employment opportunities (see the Energy Wise case study).

\section{Travel and lodging support for workforce}

One way to remediate the lack of a qualified workforce in rural areas is to reimburse travel and lodging costs for auditors, vendors, and contractors. For example, in Alaska, the efficiency program provided travel expense reimbursement for auditors when three or more home ratings were needed in a rural community (AEA 2018). In Maine, the Island Institute has used grant funding to provide ferry tickets and lodging to contractors, reducing the barriers to serving remote island communities by simplifying the complex logistics and eliminating the additional costs of serving these places (Macdonald, Island Institute, Personal Communication, August 2018).

\section{Combining forces and resources}

Many rural towns are governed by a volunteer board, with little or no paid staff to manage town business, limiting the capacity to take on larger projects or coordinate volunteers. For example, many rural Alaska communities do not have a tax base and are therefore unable to dedicate municipal resources to energy efficiency initiatives. Potential solutions to this problem include sharing an energy coordinator position across several towns, as in the "circuit rider" program run by the Adirondack North Country Association (ANCA 2019) and combining municipal building and residential building upgrades to engage an entire community, as in Alaska's Whole Village Retrofit initiatives (see the "Cross-sector collaboration" section for more details).

Case study 1: "Weatherize" campaigns take energy efficiency to the community scale Weatherize Upper Valley is an initiative addressing geographic and workforce availability barriers in Vermont and New
Hampshire. Coordinated by the nonprofit organization Vital Communities, Weatherize Upper Valley enlisted community volunteers to create their own local outreach teams responsible for increasing participation. Vital Communities invited contractors to offer free or discounted home energy consultations through a regional Request for Proposal (RFP) process and coordinated outreach with the local volunteer teams (Vital Communities 2019). This approach created economies of scale in small communities and made the vendor selection process easier for participants, allowing them to access the HPES rebates offered by Efficiency Vermont and the NHSaves program. The partnership between contractors and the volunteer teams generated leads for the contractors, helping justify the discounted services, and ensured that contractors were accountable to their customers. Pilot Weatherize campaigns in 14 Vermont towns resulted in 100 weatherization projects in just 6 months, an increase of $40 \%$ above their typical annual average. During the program's second round, six New Hampshire towns with virtually no history of weatherization projects helped weatherize over 90 homes with help from seven New Hampshire contractors. A similar Weatherize initiative in Rockland, Maine, increased participation in Efficiency Maine's rebate programs from 35 rebates awarded in 2016 to 85 rebates awarded in 2017, an increase of more than $140 \%$. The campaign also successfully reached 20 low- and moderate-income households (versus none in 2016). This model has since been replicated and adapted elsewhere in Maine, including Ellsworth and Mount Desert Island. These types of communitybased initiatives are now supported by administrators such as Efficiency Maine, which produced a Collective Purchase Toolkit (Efficiency Maine 2019a), and Efficiency Vermont, which is scaling Weatherize campaigns across the entire state. These efforts are also supported by technical resources, such as the Brighter Vermont Community Energy Dashboard (BVCED 2019) and the Alaska Energy Data Gateway (AEG 2019).

Addressing financial barriers

\section{Flexible program design}

Flexible program design allows for greater participation among rural and low-income residents. For example, 
EMHESP and Affordable Heat Initiative rebates allow participants to obtain an energy assessment and basic weatherization for as little as \$50 (Efficiency Maine 2019b). This program also permits staged upgrades, allowing homeowners to make home efficiency improvements as their budgets allow, rather than requiring that all measures be completed at once. The program also allows customer co-pays to be paid by a third party, such as a local charity or fuel assistance fund, further lowering financial barriers. Efficiency Vermont is piloting a do-it-yourself weatherization program that provides rebates to cover the cost of air sealing and insulation materials (Efficiency Vermont 2019a). The program does not require homeowners to use a certified contractor but provides guidance to help homeowners perform the work correctly.

\section{Innovative repayment options}

On-bill repayment programs, flexible enough for customers with creditworthiness issues, can be an effective tool by allowing consumers to pay for home energy improvements or efficient heating/ cooling system upgrades over time. Green Mountain Power, the largest utility in Vermont, is piloting a partnership with NeighborWorks of Western Vermont's Heat Squad program to integrate financing of thermal efficiency measures, such as weatherization, into its customers' electricity bills. Administrators are also developing loan products to increase participation in hard-to-serve populations. Efficiency Vermont's Heat Saver Loan and Efficiency Maine's Home Energy Loan are designed specifically for low- and moderate-income residents. For example, Efficiency Maine offers loans with no fees and fixed interest rates to homeowners with credit scores as low as 580 and terms as long as 10 years. Efficiency Vermont offers interest rates as low as $0.99 \%$ for income-eligible homeowners (Efficiency Vermont 2019b; Efficiency Maine 2019c).

Case study 2: "Weatherization Weeks" connecting island residents to air sealing and insulation services The Island Institute's award-winning ${ }^{5}$

\footnotetext{
5 The Island Institute received Efficiency Maine's Customer of the Year award in 2013 for its work connecting island residents to Efficiency Maine programs through Weatherization Weeks.
}

Weatherization Week model eliminates barriers to participation in energy efficiency financial assistance programs for island communities by aggregating the demand for energy assessments and air sealing and deploying these services in bulk over the course of a single week (Island Institute 2019). Unlike Weatherize initiatives, a Weatherization Week focuses on completing as many energy efficiency upgrades as possible over the course of 1 week, making it well suited to remote communities that are difficult for contractors to access. Energy assessments and basic air sealing for 8-10 homes are scheduled over a week's time, using rebates available through Efficiency Maine to keep the cost of participation as low as $\$ 50$ out of pocket. The Weatherization Week approach reduces the logistical challenges, lowers the cost of participation, builds local awareness of available financial assistance (e.g., rebates, loans), and increases uptake of additional efficiency measures in the future (e.g., heating system upgrades, lighting retrofits). Efficiency Maine's flexible program design, which allows customers to install weatherization measures in stages, according to their budgets, enabled islanders of all income levels to participate in the program (Efficiency Maine 2019b).

Using the Weatherization Week model, Monhegan Island, a small island 12 miles offshore (with a year-round population of approximately 70 and a median household income of $\$ 26,250$ ), successfully weatherized more than $85 \%$ of its year-round homes. The impacts of Weatherization Weeks in island communities throughout the state have been significant. Between 2010 and 2011, only 13 island homes participated in a previous iteration of HESP. Since 2012, when a redesigned, more flexible HESP was launched and the Island Institute began partnering with communities and contractors, the Weatherization Week model has helped more than 400 island homeowners (comprising approximately $20 \%$ of the total year-round island housing stock) access energy efficiency services and clean-energy finance programs. These islanders have invested more than $\$ 275,000$ in energy upgrades to date, with cumulative savings of $\$ 2.5$ million (MacDonald, Island Institute, Personal Communication, August 2018). This model has been replicated in other areas of the state such, as the City of Eastport - the easternmost city in the USA - and has informed the development of other initiatives, such as the Weatherize Rockland program. 
Addressing awareness and access barriers

\section{Educating and leveraging community-based organizations}

Community-based organizations are using social networks and volunteers to increase awareness and accelerate uptake of energy efficiency. Volunteers may be interested in starting a weatherization campaign, but they may not know where to start. Some organizations have established very detailed templates and protocols that can be replicated in rural communities (see the Weatherize case study and the Energy Wise case study for details).

\section{Convening stakeholders to share information and resources}

Bringing stakeholders together to share information about program models and available resources can help address awareness and access barriers. For example, the Alaska Energy Efficiency Partnership (AEEP), coordinated by the Alaska Energy Authority since 2010, is improving the coordination of efforts to increase uptake of energy efficiency across the state (AEEP 2019). AEEP brings stakeholders together for quarterly meetings, so they can share information and resources. Similarly, the Vermont Energy Investment Corporation convened a series of stakeholder meetings and a "North Country Energy Efficiency Value Chain Workshop" in 2018 focused on identifying ways to address barriers to energy efficiency in Coös County, New Hampshire, the northernmost part of the state (VEIC 2019). In Maine, the United Way of Midcoast Maine hosts "Heating Meetings" each fall in which resource agencies and other partners from around the Midcoast region share information about resources available for low-income households, including weatherization programs and fuel assistance (MacDonald, Island Institute, Personal Communication, August 2018).

\section{Cross-sector collaboration}

Partnerships that are designed to address multiple local priorities are also showing promise in engaging hard-to-serve populations. Working across sectors can be particularly impactful in rural communities where, for example, small business owners, homeowners, and community volunteers are often one and the same. The Maine Climate Table (MCT), a statewide partnership of individuals and organizations from the business, nonprofit, philanthropic, and government sectors working to increase civic engagement on climate action, actively supports cross-sector outreach to increase participation in energy efficiency programs by ensuring that there is "no wrong door to warmth" (MCT 2019). As a result, the Island Institute, a MCT member, partnered with Mano en Mano, a nonprofit that works with agricultural workers and immigrants in rural parts of the state, to host a Weatherization Week targeting Spanish-speaking households (Mano en Mano 2019). This partnership allowed a population that, due to geographic isolation and language barriers, had not been able to access financial assistance programs to make much-needed energy efficiency upgrades in their homes. In Alaska, the Alaska Native Tribal Health Consortium has begun integrating energy efficiency into its existing outreach efforts to help Alaskan villages develop crucial water and sanitation infrastructure (ANTHC 2019). Similarly, the Alaska Energy Authority's Whole Village Retrofit project in the remote village of Nightmute included community-owned residential buildings, such as teacher housing, in addition to municipal and commercial buildings (AEA 2009). This cross-sector approach helps leverage limited resources and takes advantage of the knowledge that individuals working in rural, publicly owned facilities can also be effective champions for residential energy efficiency.

Case study 3: Energy Wise outreach program lays the foundation for energy efficiency action A 2011 report commissioned by the Alaska Energy Authority (AEA) highlights the importance of combining effective education and behavior change with a clear path for consumers to follow to improve energy efficiency in their homes (Lister and Ives 2011). After conducting the needs assessment, AEA tested a suite of outreach and engagement strategies. It identified the Rural Alaska Community Action Program (RurAL CAP)'s Energy Wise program, and its community energy efficiency education "Booth in a Bucket" kit, as the most effective and replicable models for overcoming the barriers to adoption of energy efficiency (AEA 2013). Energy Wise was implemented alongside community-wide weatherization initiatives supported by the Weatherization 
Table 3 Barriers and bridging models expressed in 3 case studies

\begin{tabular}{|c|c|c|}
\hline Case study & Barriers addressed & Bridging strategies used \\
\hline $\begin{array}{l}\text { Vermont and New Hampshire: Weatherize } \\
\text { Upper Valley }\end{array}$ & $\begin{array}{l}\text { - Workforce availability } \\
\text { - Upfront cost } \\
\text { - Lack of access to traditional marketing } \\
\text { channels } \\
\text { - Lack of awareness or skepticism of } \\
\text { existing resources }\end{array}$ & $\begin{array}{l}\text { - Aggregated demand and collective } \\
\text { purchasing } \\
\text { - Community partnerships } \\
\text { - Educating and leveraging community-based } \\
\text { organizations } \\
\text { - Cross-sector collaboration }\end{array}$ \\
\hline Maine: Weatherization Weeks & $\begin{array}{l}\text { - Geographic Isolation } \\
\text { - Workforce availability } \\
\text { - Upfront cost } \\
\text { - Lack of access to traditional marketing } \\
\text { channels } \\
\text { - Lack of awareness or skepticism of } \\
\text { existing resources }\end{array}$ & $\begin{array}{l}\text { - Aggregated demand and collective } \\
\text { purchasing } \\
\text { - Community partnerships } \\
\text { - Travel and lodging support for workforce } \\
\text { - Flexible program design } \\
\text { - Educating and leveraging community-based } \\
\text { organizations } \\
\text { - Cross-sector collaboration }\end{array}$ \\
\hline Alaska: Energy Wise & $\begin{array}{l}\text { - Geographic Isolation } \\
\text { - Lack of awareness of existing resources }\end{array}$ & $\begin{array}{l}\text { - Hire and train local labor } \\
\text { - Educating and leveraging community-based } \\
\text { organizations }\end{array}$ \\
\hline
\end{tabular}

Program, which provided $\$ 30,000$ per home for energy efficiency upgrades and enhanced the efficacy of these weatherization projects by engaging homeowners through neighbor-to-neighbor outreach and energy education. RurAL CAP hired local crews and trained them in building science and weatherization. These local crews conducted basic home energy assessments and talked with homeowners about the best options for reducing their energy use. The crews then installed $\$ 300$ worth of energy efficiency supplies and demonstrated to participants how they could save more energy in their homes through energy conservation and behavior-change techniques (John 2016).

The Booth in a Bucket kits provide a simple, culturally relevant, and transportable system to engage communities in the fundamentals of energy efficiency and conservation. Designed for use in remote Alaskan villages, the kits contain interactive activities that demonstrate home energy concepts, as well as a list of materials and step-by-step instructions about how to organize an energy fair in a community. The activities demonstrate how insulation works, how heat is transferred, and how air flows in a house. The kits can be assembled for approximately $\$ 100$ each and easily fit into a standard five-gallon bucket, making them accessible to communities reachable only by small plane. Between 2009 and 2012, the Energy Wise program was implemented in 18 communities and 1530 households, helping save an average of $\$ 700$ per household per year (AEA 2013).

\section{Conclusion}

Our research demonstrates that the barriers to adoption of energy efficiency can be significant in rural and remote heating-dominated areas and can differ from those seen in more densely populated areas. These barriers fall into three distinct categories: geographic barriers, financial barriers, and awareness and access barriers. As demonstrated in our three case studies, there are numerous methods that have proven successful in bridging these gaps in rural and remote areas (Table 3).

To address geographic barriers, communities and organizations can (1) create geographically equitable program designs, (2) utilize aggregated demand and collective purchasing, (3) leverage community partnerships, (4) hire and train local labor, (5) provide travel and lodging support for contractors and others, and (6) combine forces and resources across communities.

To address the financial barriers, communities and organizations can (1) utilize flexible program design rather than a one-size-fits-all approach and (2) utilize innovative financing options that are accessible and attractive to rural residents.

To address awareness and access barriers, communities and organizations can (1) educate and leverage 
community-based organizations, (2) convene stakeholders to share information and resources, and (3) encourage and utilize cross-sector collaborations.

While none of these approaches represents a panacea for dealing with the rural energy efficiency gap in heating-dominated regions, each represents a proven method for dealing with the barriers identified in this research. The challenges to rural communities vary, and each will require their own approach to expanding access to and uptake of energy efficiency projects. However, this research provides clear examples of how residents of four rural states can move projects forward given their own unique barriers and opportunities.

\section{Recommendations}

There are many differences between rural areas across the country, e.g., demographics, utility model and rate structures, energy sources, and consumption patterns. This paper is not intended to suggest that the strategies documented here will necessarily be applicable to all rural areas in the USA. However, acknowledging that there are additional barriers to energy efficiency in rural areas is an important first step. Policymakers, administrators, and implementers can and should work together to design and deploy bridging models like the ones outlined in this paper that lower barriers to accessing financial assistance for energy upgrades. Bridging models and programs that reduce geographic, financial, awareness, and access barriers can accelerate uptake of energy-saving measures in rural areas and have the potential to reduce the degree to which the energy burden is impacting rural households and local economies. Partnering across sectors and leveraging the resources of federal agencies such as USDA Rural Development, Community Action Agencies, and community-based organizations can amplify the impact of these efforts. The approaches that Alaska, Maine, New Hampshire, and Vermont are developing serve as examples of the bridges that can connect rural America to a more efficient and prosperous future.

More research is necessary to determine whether and to what extent the rural efficiency gap exists in other regions, as well as in housing sectors not covered by this paper, such as multifamily and/or rental homes and homes in cooling-dominated regions as well as regions with both significant heating and cooling. Additional research should also examine the potential for residents to leverage the resources of multiple energy efficiency programs. The increasing focus on these issues from efforts such as the ACEEE rural research initiative (ACEEE 2018) and the National Association of State Energy Officials (NASEO 2019) allows researchers to address these research gaps and continue to support dialog and the exchange of information on these topics among key stakeholders.

Acknowledgments The authors wish to thank the advisors of the Bridging the Rural Efficiency Gap project for their valuable feedback and contributions to this paper. These advisors include Sarah Brock, Vital Communities; Katie Conway, Alaska Energy Authority; Joe Doiron, New Hampshire Office of Strategic Initiatives; Bridget Doxsee, Efficiency Maine; Dana Fischer, Mitsubishi Electric; Agnes Gormley, Maine Office of the Public Advocate; Shaina Kilcoyne, Renewable Energy Alaska Project; Paul Markowitz, Efficiency Vermont; and Brandi Martin, U.S. Department of Energy. Special thanks also go to the Island Institute staff involved in the research and development of this paper: Marydale Abernathy, Nick Battista, Harry Podolsky, and Jack Sullivan. This paper was created with the support of the U.S. Department of Energy's State Energy Program and philanthropic donors of the Island Institute including the Elmina B. Sewall Foundation, the Horizon Foundation, and Jane's Trust Foundation.

Funding This material is based on work supported by the U.S. Department of Energy, Office of Energy Efficiency and Renewable Energy (EERE), under Award Number DE-EE0007780.

\section{Compliance with ethical standards}

Conflict of interest The authors declare that they have no conflicts of interest.

Disclaimer This paper was prepared as an account of work sponsored by an agency of the U.S. Government. Neither the U.S. Government nor any agency thereof, nor any of their employees, makes any warranty, express or implied, or assumes any legal liability or responsibility for the accuracy, completeness, or usefulness of any information, apparatus, product, or process disclosed, or represents that its use would not infringe privately owned rights. Reference herein to any specific commercial product, process, or service by trade name, trademark, manufacturer, or otherwise does not necessarily constitute or imply its endorsement, recommendation, or favoring by the U.S. Government or any agency thereof. The views and opinions of authors expressed herein do not necessarily state or reflect those of the U.S. Government or any agency thereof. 
Open Access This article is distributed under the terms of the Creative Commons Attribution 4.0 International License (http:// creativecommons.org/licenses/by/4.0/), which permits unrestricted use, distribution, and reproduction in any medium, provided you give appropriate credit to the original author(s) and the source, provide a link to the Creative Commons license, and indicate if changes were made.

\section{References}

Adirondack North Country Association (2019). Circuit Rider's Program. Accessed February 1, 2019. https://www. adirondack.org/energy-circuit-riders.

Alaska Energy Authority (2009). Village Energy Efficiency Program. Accessed July 24, 2018. http://www. akenergyauthority.org/Efficiency/veep.

Alaska Energy Authority (2013). Community energy efficiency education "Booth in a Bucket" kits - implementation model. Implementation Model, Alaska Energy Authority. http://www.akenergyauthority.org/programs/AEE/EEC. Accessed 24 July 2018.

Alaska Energy Authority (2017). Energy efficiency \& conservation. Accessed April 19, 2018. http:/www.akenergyauthority. org/Efficiency.

Alaska Energy Authority (2018). Weatherization and Home Energy Rebate Program Units by AEA Energy Region 2008-2015.

Alaska Energy Data Gateway (2019). Accessed February 1, 2019. https://akenergygateway.alaska.edu/.

Alaska Energy Efficiency Partnership (2019). Accessed February 1, 2019. http://www.akenergyefficiency.org/about-us/.

Alaska Native Tribal Health Consortium (2019). Accessed February 1, 2019. https://anthc.org/.

American Council for an Energy Efficient Economy (2018). Rural and small-town communities. Accessed June 22, 2018. http:/ aceee.org/topics/rural-and-small-town-communities.

Brighter Vermont Community Energy Dashboard (2019) Accessed February 1, 2019 . https://www. vtenergydashboard.org/.

Bureau of Labor Statistics (2013). Expenditures of urban and rural households in 2011. February. Accessed July 25, 2018. https:/www.bls.gov/opub/btn/volume-2/expenditures-ofurban-and-rural-households-in-2011.htm\#_edn1.

Census Bureau (2016). American community survey 5-year estimates, Housing units, median year structures built.. https://factfinder.census.gov/faces/tableservices/jsf /pages/productview.xhtml? src=CF. Accessed 20 Mar 2018.

Department of Energy (2016). Energy efficiency efforts in Alaska | Department of Energy. June 27. Accessed March 20, 2018. https:/www.energy.gov/eere/ampedup/articles/energyefficiency-efforts-alaska.

Department of Energy (2015). Low-Income Energy Affordability Data (LEAD) Tool. Accessed June 6, 2018. https:/openei. org/doe-opendata/dataset/celica-data.

Efficiency Maine (2018). Contractors providing air sealing and assessment. Accessed March 27, 2018. https:/www. efficiencymaine.com/at-home/vendor-locator/.
Efficiency Maine (2019a). Collective Purchase toolkit. Accessed February 1, 2019. https://www.efficiencymaine.com/athome/collective-purchase/.

Efficiency Maine (2019b). Home Energy Savings Program. Accessed February 1, 2019. https://www.efficiencymaine. com/at-home/home-energy-savings-program/.

Efficiency Maine (2019c). Home Energy Loan. Accessed February 1, 2019. https://www.efficiencymaine.com/athome/energy-loans.

Efficiency Vermont (2018). Home performance contractors. Accessed March 27, 2018. https:/ www.efficiencyvermont. com/find-contractor-retailer.

Efficiency Vermont (2019a). DIY Weatherization program. Accessed February 1, 2019. https:/www.efficiencyvermont. $\mathrm{com} / \mathrm{rebates} /$ list/diy-weatherization.

Efficiency Vermont (2019b). Heat Saver loan program. Accessed February 1, 2019. https:/www.efficiencyvermont. com/rebates/list/diy-weatherization.

EMI Consulting (2014). Emera Maine Heat Pump Pilot Program. Final Report, Seattle, WA: EMI Consulting. Accessed 2018.

Energy Information Agency (2016). Maine - compare - U.S. Energy Information Agency (EIA). Accessed March 20, 2018. http://www.eia.gov/state/compare/?sid= ME\#?selected=ME-NH.

Energy Futures Group (2018). Vermont Clean Energy Finance Report. Accessed December 20, 2018. https://publicservice. vermont.gov/sites/dps/files/documents/Renewable Energy/CEDF/Reports/Vt._Clean_Energy_Finance Rpt_2018.pdf

Environmental Defense Fund (2018). Low-income energy efficiency, a pathway to clean, affordable energy for all. Accessed June 28, 2018. https:/www.edf.org/sites/default/ files/documents/liee_national_summary.pdf.

Fisher Sheehan and Colton (2017). Home energy affordability gap. Accessed June 29, 2018. http:/ www. homeenergyaffordabilitygap.com/index.html.

Fowlie, M., Greenstone, M., \& Wolfram, C. (2018). Do energy efficiency investments deliver? Evidence from the Weatherization Assistance Program. The Quarterly Journal of Economics., 33(3), 1597-1644.

GDS Associates, Inc. (2018). Maine low-income household energy efficiency baseline study. Final Report, Augusta, Maine: The Maine Office of the Public Advocate.

Gerarden, T., Newall, R., Stavins, R. (2015) Deconstructing the Energy-Efficiency Gap: Conceptual Frameworks and Evidence. American Economic Review 105(5)183-86

Gilleo, A (2018). Rural energy burdens and energy efficiency opportunities. NASEO 2018 Energy Policy Outlook Conference. February 8. energyoutlook. naseo. org/data/energymeetings/presentations/Gilleo\%2D\%2 DRural-Energy-Burden.pdf. Accessed 20 Mar 2018.

Gillingham, K., \& Palmer, K. (2014). Bridging the energy efficiency gap: policy insights from economic theory and empirical evidence. Review of Environmental Economics and Policy. https://doi.org/10.1093/reep/ret021.

Island Institute (2018). Bridging the Rural Efficiency Gap toolkit. http:/www.islandinstitute.org/bridging-rural-efficiency-gap. Accessed 15 Dec 2018.

Island Institute (2019). Weatherization Week model. Ahttp://www. islandinstitute.org/what-works/high-cost-energy. 
Jaffe, A. B., \& Stavins, R. N. (1994). The energy-efficiency gap what does it mean? Energy Policy, 22(10), 804-810.

John, J. (2016). Rural Alaska Community Action Program, Inc.'s Energy Wise Program. Accessed July 1, 2018. https:/www. energy.gov/sites/prod/files/2016/02/f30/14_jolene _ john tues0429.pdf.

Juillerat, J. (2018). Vermont energy investment corporation personal communication. Communications between authors and staff members involved in energy programs related to weatherization and energy efficiency.

Lister, C., \& Ives, D. (2011). Recommendations for Alaska Energy Efficiency and Conservation Public Education and Outreach. Anchorage: Alaska Energy Authority.

MacDonald, S. (2018). Island Institute personal communication. Communications between authors and staff members involved in energy programs related to weatherization and energy efficiency.

Maine Climate Table (2019). Accessed February 1, 2019. https://www.maineclimatetable.org/.

Maine State Housing Authority (2019). Home Improvement Program details. Accessed February 1, 2019. http://www. mainehousing.org/programs-services/HomeIm provement/homeimprovementdetail/weatherization.

Mano en Mano (2019). Accessed February 1, 2019. https://www. manomaine.org/.

Mooney, C. (2015). Alaska's quest to power remote villages and how it could spread clean energy worldwide. Washington Post. August 14. Accessed March 20, 2018. https:/www. washingtonpost.com/news/energy-environment/wp/2015/08 /14/how-alaskas-quest-to-power-remote-villages-could-helpthe-rest-of-the-planet/?utm term=.02f4afba9615.

National Academies of Sciences, Engineering, and Medicine. (2016). Electricity use in rural and islanded communities: summary of a workshop. Washington, DC: The National Academies Press. https://doi.org/10.17226/23539.

National Association of State Energy Offices (2019). Statewide comprehensive energy plans. Accessed March 25, 2019. https://naseo.org/stateenergyplans.

NMR Group, Inc. (2015). Maine single-family residential baseline study. Reports, Efficiency. Maine. September 14. Accessed October 15, 2018. https:/www.efficiencymaine. com/docs/2015-Maine-Residential-Baseline-Study-ReportNMR.pdf.
Regional Greenhouse Gas Initiative (2019). Accessed February 1, 2019. https://www.rggi.org/.

Ross, L., Drehobl, A., and Stickles, B. (2018). The high cost of energy in rural America: Household Energy Burdens and Opportunities for Energy Efficiency. July. Accessed August 6, 2018. http:/aceee.org/research-report/u1806.

Sears, J. (2018). Characterizing residential energy burden in Coös County, New Hampshire. White Paper: Vermont Energy Investment Corporation.

Shoemaker, M., Gilleo, A., and Ferguson, J. (2018). Reaching rural communities with energy. Efficiency Programs. September 19. Accessed October 15, 2018. https://aceee. org/research-report/u1807.

Vermont Department of Public Service (2011) 2011 Comprehensive Plan. https://publicservice.vermont. gov/publications-resources/publications/energy_plan/2011 plan.

Efficiency Vermont (2017) Efficiency Vermont HPwES participation data. Accessed December 19, 2018. https://www. efficiencyvermont.com/Media/Default/docs/plans-reportshighlights/2017/efficiency-vermont-annual-report-2017.pdf

Vermont Energy Investment Corporation (2019). Building wealth and reducing energy burden in the North Country. Accessed February 1, 2019. https://www.veic.org/mediaroom/insights/insights/2019/01/30/building-wealth-andreducing-energy-burden-in-the-north-country.

Vermont Public Utility Commission (2017) Triennial Plan 2018 2020, Prepared for the Vermont Public Utility Commission. https://www.efficiencyvermont.com/about/annual-plansreports. Accessed 15 Nov 2018

Vital Communities (2019) Weatherize Upper Valley. Accessed February 1, 2019. https://vitalcommunities. org/energy/weatherize/.

Yuan, G. (2015). Rural electrification goes local: recent innovations in renewable generation, energy efficiency, and grid modernization. IEEE Electrification Magazine., 3(1), 16-24.

Publisher's note Springer Nature remains neutral with regard to jurisdictional claims in published maps and institutional affiliations. 